\title{
THE DETERMINATION OF SERUM IRON AFTER THE INTRAVENOUS INJECTION OF IRON-DEXTRAN
}

\author{
BY \\ D. WEBSTER \\ From the Department of Medicine and Geriatric Medicine, the General Hospital, Sunderland
}

(RECEIVED FOR PUBLICATION FEBRUARY 12, 1960)

\begin{abstract}
A rapid technique for the determination of iron in serum, after the intravenous injection of iron-dextran, is presented.

Dithionite is used for the reduction of ferric to ferrous iron.

The use of a detergent solution enables protein precipitation to be omitted.

The iron reagent, 4:7-diphenyl-1:10-phenanthroline, and its ferrous complex are both soluble in the dilute detergent solution.

Lipaemic serum can be used without affecting the results.

The recovery of added ferric iron, as iron-dextran, is quantitative.
\end{abstract}

The introduction by MacKenzie and Tindle (1959) of an iron-dextran compound for the measurement of plasma volume has increased the necessity for an accurate and rapid technique for serum iron determination in the concentration range 500-2,500 $\mu \mathrm{g}$. Fe $/ 100 \mathrm{ml}$. The determination of serum iron described by MacKenzie and Tindle is a modification of the method of Trinder (1956) which involves protein precipitation before colour development with the sulphonated $4: 7$-diphenyl-1: 10-phenanthroline (bathophenanthroline) reagent. In an attempt to simplify this technique it was decided to investigate the possibility of omitting protein precipitation. If this could be achieved time would be saved, smaller volumes of serum would be required, and the risk of contamination would be reduced since the determination would be completed in one test-tube.

Dilute solutions of detergents were found to be effective in preventing precipitation of the serum proteins during colour development at a temperature of 90 to $95^{\circ} \mathrm{C}$. Despite high protein concentrations and prolonged boiling, perfectly clear solutions were obtained. The commonly used detergent " teepol " (Shell Chemical Limited) was found to be very satisfactory and has been used in this investigation. The bathophenanthroline reagent and its red ferrous complex, both normally insoluble in aqueous solution, are readily soluble in dilute solutions of the detergent; sulphonation with chlorosulphonic acid was therefore unnecessary. The method is rapid and accurate and can be done routinely in any clinical laboratory.

\section{Method}

Apparatus and Reagents.-All apparatus should be rendered iron-free by any of the conventional methods. Thereafter the test-tubes simply require rinsing in distilled water after each batch of determinations. Although the " teepol " used was ordinary commercial grade as supplied for cleansing purposes it was surprisingly free from iron and required no preliminary treatment. Teepol powder ("teepol XL") can also be obtained, but this contains considerably more iron than the liquid concentrate and was not used in this study. The distilled water used throughout was rendered iron-free by passage through an "elgalite" ion-exchange resin. The reagent blank was of the order of $0.2 \mu \mathrm{g}$. Fe/determination, but about half of this "iron" was due to the colour of the iron reagent.

Iron Reagent.-Dissolve $5 \mathrm{mg}$. 4:7-diphenyl-1:10phenanthroline in $10 \mathrm{ml}$. liquid "teepol " concentrate (27\% active ingredient) by warming on a hotplate and breaking down any lumps with a glass rod. After cooling make the volume to $100 \mathrm{ml}$. with distilled water. When larger volumes of iron reagent are required the preparation of a stock solution containing $50 \mathrm{mg}$. bathophenanthroline $/ 100 \mathrm{ml}$. "teepol" concentrate is recommended. The working reagent is obtained by diluting this stock solution 1 in 10 with water. The reagent appears to keep indefinitely.

Reducing Agent. - Solid sodium hydrosulphite (dithionite) $\mathrm{Na}_{2} \mathrm{~S}_{2} \mathrm{O}_{4}+\mathrm{H}_{2} \mathrm{O}$, which should be of the highest available purity.

Standard Iron Solution ( $1 \mathrm{mg} . \mathrm{Fe} / \mathrm{ml}$.).-Dissolve $702 \mathrm{mg}$. A.R. grade ferrous ammonium sulphate $\left(\left(\mathrm{NH}_{4}\right)_{2} \mathrm{SO}_{4}\right.$. $\left.\mathrm{FeSO}{ }_{4} 6 \mathrm{H}_{2} \mathrm{O}\right)$ in $\mathrm{N} / 10$ sulphuric acid and make the volume to exactly $100 \mathrm{ml}$. with the acid. 
Procedure.-Treat both blank and test sera (or heparinized plasma) as follows:

Deliver $0.2 \mathrm{ml}$. serum into a $15 \mathrm{ml}$. " pyrex" testtube containing $3.8 \mathrm{ml}$. iron reagent and $10-20 \mathrm{mg}$. dithionite.

Mix by lateral shaking and place in a water-bath at $90-95^{\circ}$ C. for three minutes.

Remove and cool to room temperature.

Read the optical density of the test solution against the blank in the spectrophotometer at $530 \mathrm{~m} \mu$.

Standards.-Prepare working standards by diluting the standard iron solution ( $1 \mathrm{mg}$. $\mathrm{Fe} / \mathrm{ml}$.) 3 in 200 and 3 in 100 with distilled water to give solutions containing 15 and $30 \mu \mathrm{g}$. Fe $/ \mathrm{ml}$. Treat $0.2 \mathrm{ml}$. of these diluted standards ( $\mathrm{S}_{1}$ and $\mathrm{S}_{2}$ ) exactly as described for serum or plasma and read the optical densities of the resulting solutions in the spectrophotometer against a reagent blank. As there is complete agreement with Beer's law the optical density of $S_{2}$ should be exactly twice that of $S_{1}$. Using a "unicam" SP. 600 spectrophotometer at $530 \mathrm{~m} \mu$ and with $10 \mathrm{~mm}$. cells, an optical density of $0.092 / \mu \mathrm{g}$. Fe was obtained.

Calculation.-This is as follows :

Iron content of test $=\frac{\text { O.D. of test }}{\text { O.D. of } S_{1}} \times 15$, or $\frac{\text { O.D. of test }}{\text { O.D. of } S_{2}} \times 30 \mu \mathrm{g} . / \mathrm{ml}$.

For instruments which require up to $5 \mathrm{ml}$. of final solution the volume of iron reagent may be increased to $4.8 \mathrm{ml}$.

Iron Injected.-To determine the exact amount of iron injected, dilute the injection solution with distilled water to contain approximately $20 \mu \mathrm{g}$. Fe/ml. Treat $0.2 \mathrm{ml}$. of this solution exactly as described for serum or plasma and read in the spectrophotometer against a reagent blank to obtain $\mu \mathrm{g}$. $\mathrm{Fe} / 0.2 \mathrm{ml}$. solution.

Then

Iron injected per ml. $=\frac{\mu \mathrm{g} . \mathrm{Fe} / 0 \cdot 2 \mathrm{ml} . \times 5 \times \text { dilution factor }}{1,000} \mathrm{mg}$.

The plasma volume can now be calculated in the usual way by dividing the $\mu \mathrm{g}$. iron injected by the difference in iron content of the blank and test sera.

Plasma volume $=\frac{\mu \mathrm{g} \text {. iron injected }}{\text { iron conten: of test i i } \mathrm{n} \text {.la }\left(u_{\mathrm{g}} / \mathrm{ml} .\right)} \mathrm{ml}$.

\section{Results}

Recovery experiments were carried out by adding known amounts of iron, in the form of iron-dextran, to pooled serum. Analysis of the resulting sera by the proposed method showed that the recovery was quantitative (Table I).

TABLE I

RECOVERY OF IRON ADDED TO SERUM

\begin{tabular}{|c|c|c|}
\hline $\begin{array}{c}\text { Iron Added } \\
\text { ( } \mathrm{gg} . \mathrm{Fe} / 100 \mathrm{ml} . \text { Serum) }\end{array}$ & $(\mu \mathrm{g} . \mathrm{Fe} / 100 \mathrm{ml}$. Serum $)$ & $\%$ Recovery \\
\hline $\begin{array}{r}500 \\
1,000 \\
1,500 \\
2,000 \\
2,500\end{array}$ & $\begin{array}{r}515 \\
1,000 \\
1,480 \\
2,050 \\
2,490\end{array}$ & $\begin{array}{c}103 \\
100 \\
98 \cdot 7 \\
102 \cdot 5 \\
99 \cdot 6\end{array}$ \\
\hline
\end{tabular}

TABLE II

RESULTS OF DUPLICATE DETERMINATIONS OF IRON IN SERUM SAMPLE

\begin{tabular}{|c|c|c|c|c|c|}
\hline \multicolumn{2}{|c|}{ Optical Density } & \multirow{2}{*}{$\begin{array}{c}\text { Serum } \\
\text { Sample } \\
(\mu \mathrm{g} . \\
\mathrm{Fe} / \mathrm{ml} .)\end{array}$} & \multicolumn{2}{|c|}{ Optical Density } & \multirow{2}{*}{$\begin{array}{c}\text { Serum } \\
\text { Sample } \\
(\mu \mathrm{g} . \\
\mathrm{Fe} / \mathrm{ml} .)\end{array}$} \\
\hline $\begin{array}{l}\text { Standard } \\
(20 \mu \mathrm{gg} \\
\left.\mathrm{Fe}^{\prime} \mathrm{ml} .\right)\end{array}$ & $\begin{array}{l}\text { Serum } \\
\text { Sample }\end{array}$ & & $\begin{array}{c}\text { Standard } \\
(20 \mu \mathrm{g} . \\
\mathrm{Fe} / \mathrm{ml} .)\end{array}$ & $\begin{array}{l}\text { Serum } \\
\text { Sample }\end{array}$ & \\
\hline $\left.\begin{array}{l}0 \cdot 377\{ \\
0 \cdot 380 \\
0 \cdot 379\end{array}\right\}$ & $\begin{array}{l}0.338 \\
0.336 \\
0.334 \\
0.336 \\
0.339 \\
0.341\end{array}$ & $\begin{array}{l}17.93 \\
17.83 \\
17.58 \\
17.68 \\
17.89 \\
18.00\end{array}$ & $\left.\begin{array}{l}0.377 \\
0.373 \\
0.378\end{array}\right\}$ & $\begin{array}{l}0.336 \\
0.331 \\
0.338 \\
0.338 \\
0.339 \\
0.338\end{array}$ & $\begin{array}{l}17.83 \\
17.56 \\
18.12 \\
18.12 \\
17.94 \\
17.88\end{array}$ \\
\hline
\end{tabular}

Haemolysed serum cannot be used since the use of dithionite would include haem iron in the result. The use of grossly lipaemic serum does not interfere with the clarity of the final solution. To demonstrate this a 1 in 20 dilution of a lipaemic serum in physiological saline was prepared. This gave an optical density of 0.490 at $530 \mathrm{~m} \mu$; a 1 in 20 dilution of the same serum in $10 \% \mathrm{v} / \mathrm{v}$ teepol gave an optical density of 0.025 at the same wavelength. The serum used in this experiment was considerably more lipaemic than would normally be encountered in plasma volume measurements.

To demonstrate the reproducibility of the technique a number of duplicate determinations of the iron content of a serum sample were made on different occasions using a freshly prepared iron standard $(20 \mu \mathrm{g} . / \mathrm{ml}$.). The results are shown in Table II.

\section{Discussion}

Under the conditions of the test the bathophenanthroline reagent is specific for ferrous iron. Buffering of the reagent was considered unnecessary since the final solution is maintained at an acid $p \mathrm{H}$ by the addition of the dithionite; colour development is maximum over the $p \mathrm{H}$ range 3.5-7.0.

If the iron content of the test serum is low the volume of serum used can be increased to $0.5 \mathrm{ml}$., $3.5 \mathrm{ml}$. of the iron reagent then being used. With an injection of $50 \mathrm{mg}$. iron and a plasma volume of 3 litres the optical density of the final test solution will be about 0.30 using $0.2 \mathrm{ml}$. serum.

The reduction of ferric to ferrous iron with dithionite is complete within two minutes at room temperature, but heating at 90 to $95^{\circ} \mathrm{C}$. is necessary to render the final solution optically clear. Due to a slight turbidity unheated serum solutions have a higher optical density than the corresponding heated solution, and this difference decreases slowly during the first hour after mixing. The use of dithionite reduces the time for a plasma volume estimation to little more than 30 minutes from the time of injection, if heparinized 
plasma is used. Milder reducing agents, such as sodium sulphite which do not include haem iron in the result, require heating at 90 to $95^{\circ} \mathrm{C}$. for about an hour to obtain a quantitative recovery of iron. Such a procedure does not recommend itself for inclusion in a rapid technique. The use of solid dithionite is perfectly satisfactory since a good grade product contains as little as $0.3 \mu \mathrm{g}$. $\mathrm{Fe} / \mathrm{g}$. ; the addition of $100 \mathrm{mg}$. solid, five times the recommended amount, would increase the iron content of the final test solution by less than $1 \%$. The addition of $0.05 \mathrm{ml}$. of a saturated solution ( $1 \mathrm{~g}$. in $4 \mathrm{ml}$. water) of dithionite per determination is equally satisfactory, but the solution must be prepared immediately before use.
The proposed method compares favourably in accuracy with the method used by MacKenzie and Tindle, but the time for a single determination has been reduced by half. Recovery experiments were considered satisfactory.

This study has been aided by grants from the Nuffield Foundation and the Scientific and Research Subcommittee of the Newcastle Regional Hospital Board.

I wish to thank Dr. P. Trinder for much useful advice.

\section{REFERENCES}

MacKenzie, A., and Tindle, J. (1959). Lancet, 1, 333. Trinder, P. (1956). J. clin. Path., 9, 170. 